\title{
Economic perspective of indonesian rubber on agroforestry development
}

\author{
Miftahul Azis ${ }^{1 *}$, Saktyanu Kristyantoadi Dermoredjo ${ }^{1}$, Bambang Sayaka $^{1}$ and Linda \\ Purwaningrat $^{2}$ \\ ${ }^{1}$ Researcher, Indonesian Center for Agriculture Socio Economic and Policy Studies (ICASEPS), \\ Ministry of Agriculture Indonesia, Indonesia \\ ${ }^{2}$ Staff, Cooperation Bureau Ministry of Agriculture Indonesia, Indonesia
}

\begin{abstract}
Rubber commodity is one of the plantation commodities that supports agroforestry, besides that it is one of the attractors in the creation of labor in rural areas. The economic linkages around intensive plantations will affect development of rubber in agroforestry areas. Rubber agroforestry is important because demands of global trade will encourage the development of agroforestry itself. For this reason, this paper can provide a description of the rubber economy in supporting the national economy. The data used is secondary data including national and global data, especially for countries of ITRC forum group members. The analytical method uses Principal Component Analysis which is expected to provide an overview of the conditions for the development of the national rubber economy. The results showed that 55.34 percent indicated that the economic development of rubber was already export-oriented, while 8.56 percent indicated that global production would affect the decline in rubber area, while 13.70 percent of the global relative price had its own characteristics. Thus, it can be seen that the challenges ahead, need to anticipate the development of rubber cultivation, both in monoculture and agroforestry plantations, which can support each other with an interconnected agribusiness system for harmony with global demand.
\end{abstract}

Keywords: Rubber, agroforestry development, economics perspective, crops plantation

\section{Introduction}

Rubber is needed as an industrial raw material and has a wide market in international trade. Indonesia's dry rubber production until 2019 was 3.33 million tons [1] and put Indonesia as the second largest rubber producing country after Thailand. Indonesia controls nearly 26 percent of the world's total rubber production. Rubber is a leading commodity in the non-oil and gas sector, the second largest contributor to foreign exchange after palm oil (CPO). Indonesia's natural rubber exports in 2017 grew 1.4 percent when compared to 2016 and recorded an export value of 5.1 billion USD [2]. Indonesia classifies rubber as an export commodity which is the backbone of the national economy.

\footnotetext{
* Corresponding author: miftahul_azis@yahoo.com
} 
Rubber cultivation in Indonesia is mostly produced from smallholder plantations. Judging from the status of cultivation, 89 percent of rubber land comes from smallholder plantations and the rest comes from large private plantations. Rubber is a source of livelihood for 15 million rubber farmers in rural areas and a provider of employment for crumb rubber factory workers. In general, Indonesia's total plantation area and rubber production have experienced a steady increase over the past decade. The development of rubber area grew by 1.20 percent per year, from 2.38 million ha in 1980 to 3.67 million ha in 2017. The growth of rubber production experienced an average growth of 3.82 percent per year during the period 1980 to 2017 [3].

The increase in production and export of Indonesian rubber from year to year was triggered by the positive prospects for the rubber industry globally, which was marked by increasing international demand for rubber. World aggregate consumption increased by 64 percent during the period 1995-2007 [4]. The growth in rubber consumption led to an increase in the price of natural rubber in the first place, this prompted rubber farmers in producing countries to make large-scale expansion of land and production. Along with this, new exporting countries emerged, such as Laos, Vietnam, Myanmar and Cambodia. According to Gapkindo, this expansion is the main cause of the real price of rubber which tends to fluctuate and causes a downward trend [5]. The over supply of rubber commodities has not been matched by the growth in world demand for natural rubber.

The price of natural rubber has been under downward pressure to a very low level. In 2008 the price of rubber in Indonesia has decreased to reach Rp. 6,050 per kilogram, in 2012 it reached Rp. 11,333 per kilogram, but decreased in 2015 where the price only reached 10,852 per kilogram and in 2019 the price was only around Rp. 6,000 per kilogram [3]. These price fluctuations caused nearly 2.5 million small-scale rubber farmers to experience social and economic changes. In addition, farmers are also faced with existing problems, namely decreased productivity, crop pests, and erratic climate change.

The agroforestry system is a land use system by combining forestry components with other components such as agriculture, especially plantation crops. Rubber is a plantation commodity that can be used for crops that support agroforestry. Efforts to increase non-oil and gas exports, especially rubber, need serious attention. Forest as a product producer is also a potential natural resource for other purposes because the agroforestry system itself is defined as one of the land management systems based on sustainability that increases overall yields such as combining the production of agricultural crops and forest plants and / or animals simultaneously or sequentially on land, and apply management methods in accordance with the culture of the local population [6]. More specifically, the mixing pattern or combination of rubber with other plants is referred to as a Rubber Agroforestry System (RAS), which is an agroforestry pattern on rubber that aims to increase the productivity of crops, including rubber itself as the main product and also by-products such as fruits, wood, rattan, and others with an intensification system and for the benefit of rubber preservation [7].

The decline in rubber prices at the farm level has an impact on the purchasing power and welfare of farmers [8]. The low price of rubber has had an impact on the income of farmers per month, decreased investment ability of farmers to build superior rubber gardens, decreased purchasing power of farmers for primary and secondary goods, and the transfer of farmers' income sources to other sources of income other than rubber farming [9]. There has even been a change of land use from rubber farming to other, more prospective crops. Research conducted by the Fair Rubber Association also states that the volatility of world rubber prices has an impact on poverty for rubber farmers in all rubber producing countries, including Indonesia, Thailand, Viet Nam and India [10].

The economic linkages around intensive plantations will (dominantly) affect the development of rubber in agroforestry areas. Rubber agroforestry is important to pay 
attention to because the demands of global trade also drive the development of agroforestry itself. The purpose of this paper is to provide a description of the rubber economy from the perspective of international trade (macro) by (1) Identifying and classifying the factors that affect the Indonesian rubber economy (2) Indonesian rubber development through agroforestry.

\section{Methods}

This research was conducted during 2020. The data used are secondary data including national and global data, especially for countries that are members of the International Tripartite Rubber Council (ITRC) forum group, namely Indonesia, Malaysia and Thailand.

In the first objective analysis, the analysis method uses Principal Component Analysis (PCA). The choice of the PCA method is expected to provide an overview of the conditions for the development of the national rubber economy, besides that PCA statistically (1) can help in solving the multicollinearity problem between the analyzed variables, and (2) can present data with a simpler structure without losing the essence of the important information contained. in it, so that the efficiency and effectiveness of problem handling can be further improved [11].

The stages in the PCA analysis began with the collection of data on the initial variables related to the rubber economy. The data is then processed by transforming and orthogonizing it in matrix multiplication. The results of the PCA analysis produce a new data structure. The resulting score factor calculation is obtained from the multiplication of the matrix through the following equation:

$$
F_{\alpha}=\frac{1}{\sqrt{\lambda_{\alpha}}} \cdot Z_{\alpha}=Y \cdot \frac{b_{\alpha}}{\sqrt{\lambda_{\alpha}}}
$$

Where, the vector $b_{\alpha}$ is the eigenvector for the $-\alpha$ principal factor or component. The vector elements of $F_{\alpha}$ are factor scores for the main factor or component to- $\alpha$. The elements of $b_{\alpha} / \sqrt{ } \lambda_{\alpha}$ are the factor loadings for the $-\alpha$ principal factor or component. $Z_{\alpha}$ is an orthogonal matrix resulting from standardization of initial variable data.

The analysis for the second objective used a descriptive qualitative analysis method on the available data and information on the development of rubber by means of agroforestry in Indonesia. Data and information are obtained from searches on the internet and published national and international papers.

\section{Result and discussions}

\subsection{Factors affecting Indonesia's rubber economy}

The results of PCA analysis using 48 baseline data variables resulted in 7 main components that had a root characteristic above one with Initial Eignvalues reaching 91,866 percent (Table 1). The grouping of the 7 main components contains variables that have a significant effect on the Indonesian rubber economy (Table 2). The names of the variable groups of the main components produced by the PCA analysis are (1) Indonesia's rubber economic performance (2) Development of input and output prices (3) Development of rubber producers in the world (4) Consumption of rubber for the domestic downstream industry (especially tires) (5) ) Wages of plantation workers (6) World synthetic rubber prices (7) Exports of Indonesian natural rubber to America. The five initial components of the seven main components can explain the existence of Indonesia's rubber economy. The cumulative 
initial Eigenvalues in the model are 86.75 percent, which means that the rubber economy in Indonesia can be explained through the variables in the model.

The explanation for the main components that have been mentioned is as follows: The first component, namely the performance of the Indonesian rubber economy, has Initial Eigenvalues of 53.343 percent, which shows that Indonesia's rubber economic development has been export-oriented so far. The second component, with Initial Eigenvalues of 13.704 percent, shows that the rubber economy in Indonesia is influenced by price movements, both input and output prices. The third component, namely the development of rubber producers in the world, explains 8.561 percent of Indonesia's rubber economy. An interesting finding in this group of variables is that global production will affect the decline in rubber acreage in Indonesia. The Indonesian rubber economy in a global perspective is explained in the main component variable group, namely rubber consumption for the domestic downstream industry (especially the tire industry) (4.667 percent). Wages of plantation workers (4.477 percent). World synthetic rubber prices (2.878 percent). Indonesian natural rubber exports to America (2,236 percent). The remainder is explained by other variables not included in the model.

Table 1. Initial Eigenvalues of PCA

\begin{tabular}{|c|c|c|}
\hline \multirow{2}{*}{ Component } & \multicolumn{2}{|c|}{ Initial Eigenvalues } \\
\cline { 2 - 3 } & \% of Variance & Cumulative \% \\
\hline 1 & 55.343 & 55.343 \\
\hline 2 & 13.704 & 69.047 \\
\hline 3 & 8.561 & 77.608 \\
\hline 4 & 4.667 & 82.275 \\
\hline 5 & 4.477 & 86.752 \\
\hline 6 & 2.878 & 89.630 \\
\hline 7 & 2.236 & 91.866 \\
\hline
\end{tabular}

The area and production of natural rubber in Indonesia are considered to have the potential to be increased again by rejuvenating and empowering empty / unproductive agricultural lands suitable for rubber plantations, one of which is by developing rubber agroforestry systems. Rubber is a commodity that is not consumed directly and requires further processing. The industrial demand in Indonesia, especially the tire industry, is quite a large domestic consumer of natural rubber. Domestic demand for natural rubber has experienced an increasing trend from year to year [3].

The increase in demand is allegedly the government's effort to implement the Demand Promotion Scheme (DSP) policy by Indonesia in cooperation with the ITRC, where the Indonesian government implements a policy to encourage an increase in domestic natural rubber consumption with a target of increasing domestic consumption by 10 percent per year. This policy is a medium-term strategy so that in the future the natural rubber price determination will no longer depend too much on the demands of importing countries. The demand for rubber for the domestic industry in 2017 was 607.7 thousand tons, while in the previous year domestic demand was only 583.3 thousand tons.

Indonesian rubber production is more aimed at meeting export demand. The highest growth in rubber export volume occurred in 2010, amounting to 18.10 percent, to 2.35 million tons from 1.99 million tons in 2009. The decline in rubber export volume was mainly due to the decline in rubber prices on the world market. According to FAO data, the price of rubber from Indonesia has decreased. If in 2015 the price of rubber reached 503.8 US \$ / ton, then in 2016 it would drop to 479.1 US \$ / ton. In addition, the agreement on 
export restrictions by ITRC countries in which Indonesia is included also has an effect on the decline in export volume.

Rubber production is influenced by the area of producing rubber, the price of natural rubber at the producer level, the level of rainfall, and the real wage for labor in the plantation sector. The growth and production of rubber is determined by internal (genetic) and external (agro-climatic environment) factors as well as the interaction between the two, where the potential for production will be achieved if the conditions of the agro-climate environment and management are supportive [12]. Maintenance management and tapping techniques also greatly affect rubber production [13].

The world's demand for natural rubber is currently increasing, influenced by the flexibility and physical elasticity of natural rubber, which makes it a raw material that can be used in a wide variety of industrial products. Therefore, world natural rubber consumption is currently dominated by industrialized countries. The demand for rubber is a function of the price of synthetic rubber, the amount of domestic production of the tire industry, the real GDP of Indonesia, the price of natural rubber at the producer level and the demand for domestic rubber.

The price variable in the export market if it is integrated with the domestic market and vice versa. The price of natural rubber at the producer level is influenced by the exchange rate, the real price of rubber exports, domestic demand and domestic supply. The export destination country for natural rubber can represent the supply behavior of the export variable. The availability of domestic rubber supply occurred in 2016 , which was 1.3 million tons and decreased the export volume by 1.98 percent.

The rubber commodity is a source of livelihood for farmers. rubber succeeded in attracting small-scale farmers out of poverty and bringing them up social class. The results of research by the Research Center for Rubber in 2014 stated that the rubber commodity had a positive impact on poverty alleviation in the production center areas [14]. 


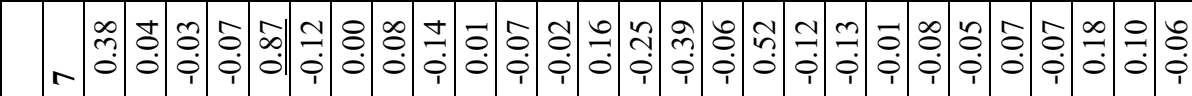

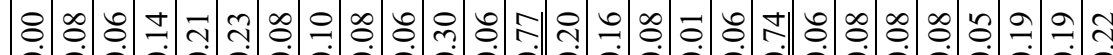

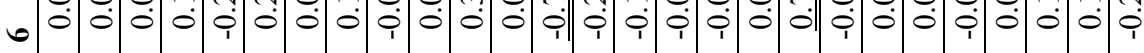

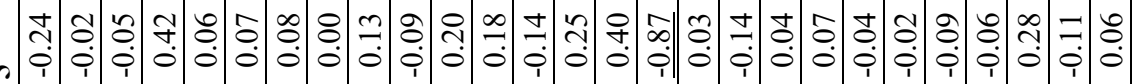

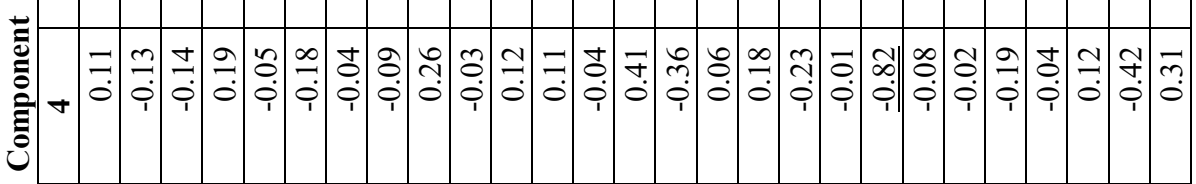

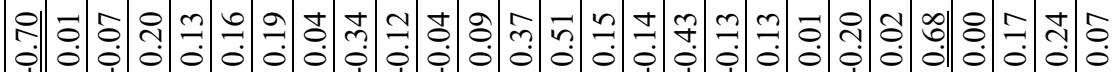
m il o i 0 o 0 o 0 i

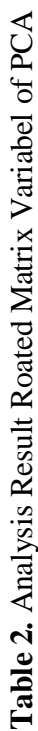

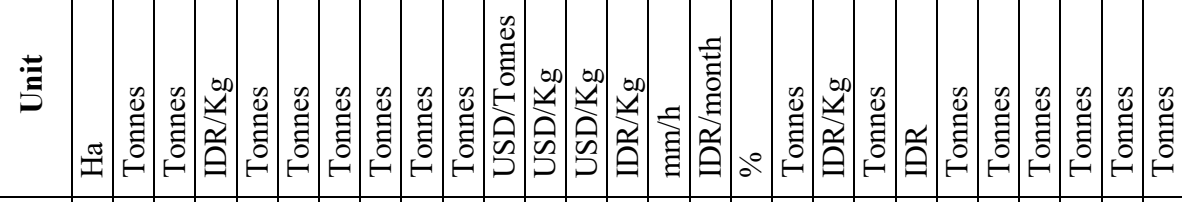

そ กิ

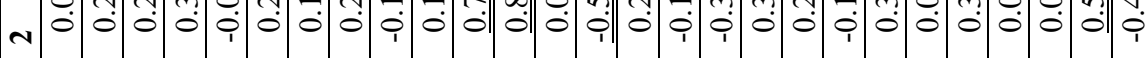

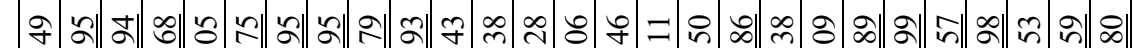

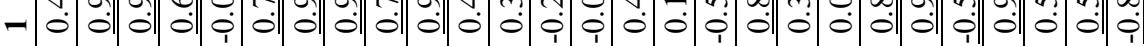

:

荡

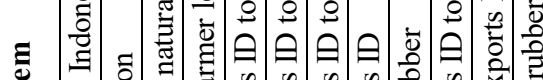

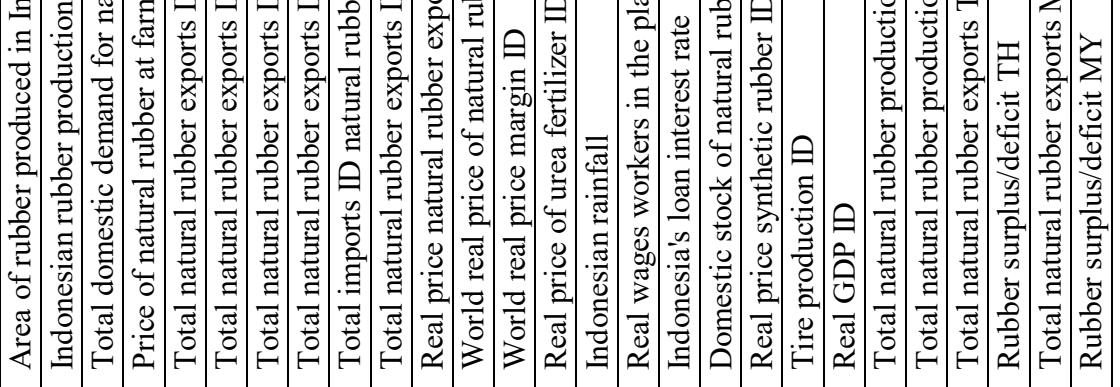

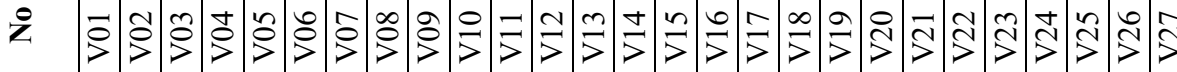




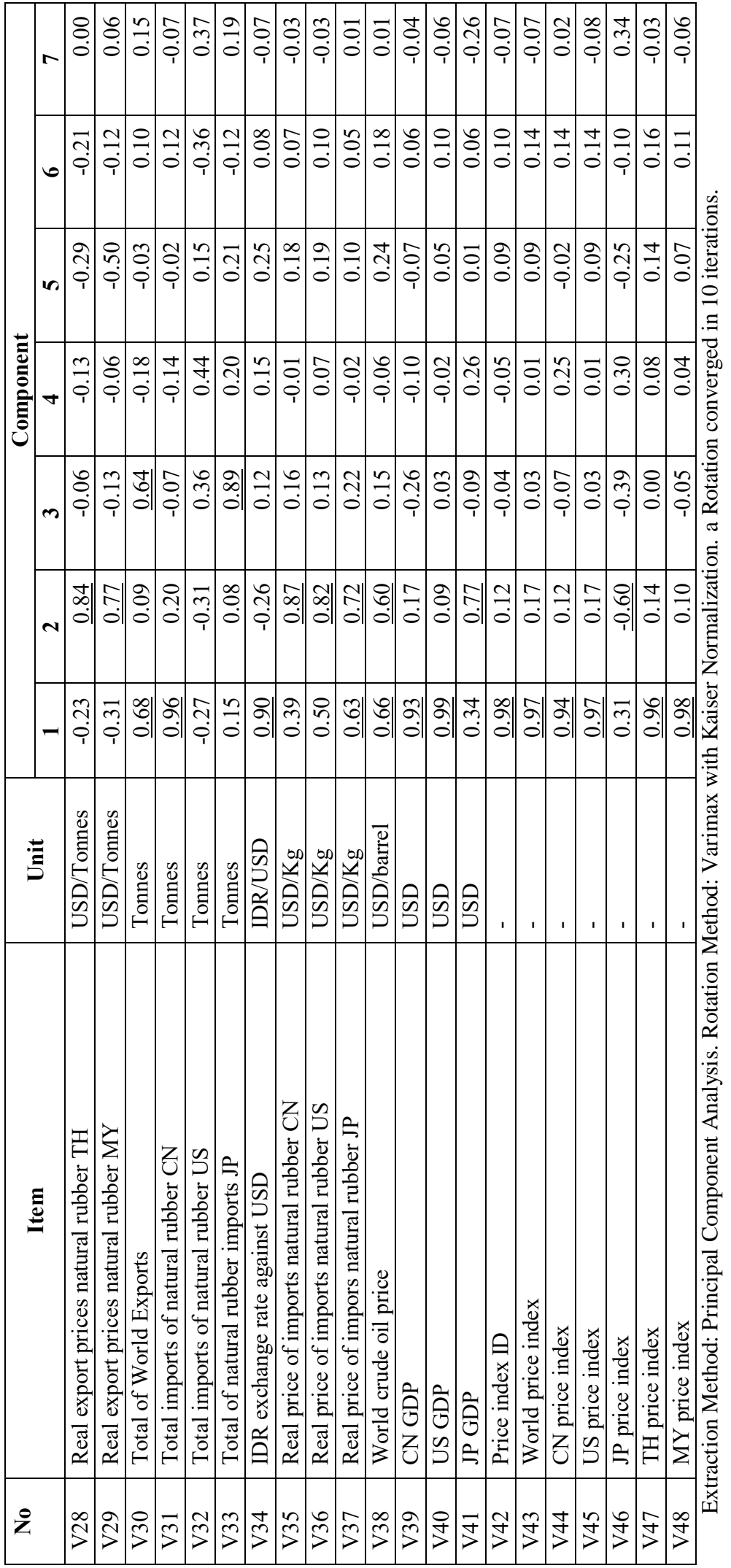




\subsection{Development of Indonesian rubber through agroforestry}

Natural rubber is a non-oil and gas agricultural commodity which is important in supporting the development of the industrial world. Natural rubber can grow optimally in tropical countries, therefore most of the world's natural rubber is produced by small farmers in developing countries in Asia (Bangladesh, Cambodia, China, India, Indonesia, Malaysia, Myanmar, Papua New Guinea, Philippines, Sri Lanka, Thailand and Vietnam), Africa (Cameroon, Ivory Coast, Ghana, Liberia, Nigeria and DR Congo) and Latin America (Brazil, Guatemala, Mexico and other Latin America), the majority of which have less rubber land of 4 hectares.

ANRPC (Association of Natural Rubber Producing Countries) said that world natural rubber production increased from 12.60 million tonnes in 2016 to 13.55 million tonnes in 2017 [15]. Global Rubber Market in its data says that in 2018 the natural rubber markets of Thailand, Indonesia and Malaysia have a wider market and an increase in demand is due to the increase in global oil prices and good weather in major producing countries so that it can support increased production. These three countries can become rubber producing countries due to several conditions, namely having a fairly large area, having natural conditions suitable for growth for the cultivation of rubber commodities, and supporting government policies [16].

The development of rubber through the agroforestry system in Indonesia is currently believed to be a traditional method of rubber cultivation and is considered unprofitable. However, the findings of a survey of 162 farmer households in the Jambi area regarding community rubber management show that community rubber management is still carried out using labor in families that are dominated by male labor. Investment in rubber by means of agroforestry is still considered profitable even though its profitability tends to decline [17].

Fulfillment of the world's demand for natural rubber has been largely derived from rubber produced from smallholder plantations with a monoculture system. The quality of rubber latex produced by monoculture is considered to provide a higher sap yield [18]. Furthermore, the comparison of the characteristics of agroforestry and monoculture is shown in Table 3. Based on the information in Table 3, it explains that in terms of the productivity of monoculture rubber cultivation gives greater results in quantity when compared to agroforestry rubber cultivation. Rubber trees in agroforestry rubber gardens are produced from old trees. The economic value of rubber lies in its ability to produce rubber latex. Rubber sap can be tapped at the age of six years and production continues to increase until the plant is 25 years old and then slowly decreases.

Both monoculture and agroforestry plantations require substantial capital investment in the process of replanting trees after their productive age. The intensive management of rubber in monoculture is suspected to be the cause of the loss of environmental functions such as soil and water conservation and flora and fauna conservation. The management of rubber by means of agroforestry is considered to have environmental benefits and is also considered to provide other economic values, namely the rubber sap itself, the wood produced from rubber trees as a source of meeting the need for wood and the economic value of other commodities that accompany rubber. Communities and local governments can make rubber agroforestry management as an alternative to meet the need for rubber by paying attention to the principles of natural resource conservation and sustainability [19].

The development of agroforestry management of rubber has prompted the World Agroforestry Center (ICRAF) to carry out many programs to develop models of agroforestry cultivation of rubber, the Rubber Agroforestry System (RAS) with the aim of increasing the production and welfare of rubber farmers. Various RAS models are presented and introduced to farmers with the hope of minimizing the impact of the massive 
clearing of rubber lands which are considered not paying attention to the principle of sustainability. Analysis of the income of agroforestry rubber cultivation farmers produced higher income when using superior clone seed rubber gardens [21].

Table 3. Comparison of rubber agroforestry with monoculture gardens.

\begin{tabular}{|c|l|c|c|}
\hline No & \multicolumn{1}{|c|}{ Description } & Rubber Agroforestry & Rubber Monoculture \\
\hline 1. & Ability to maintain nutrients & Considered more capable & Considered inadequate \\
\hline 2. & $\begin{array}{l}\text { Soil and water conservation } \\
\text { function }\end{array}$ & Pay attention & Tend not to pay attention \\
\hline 3. & $\begin{array}{l}\text { The function of flora and fauna } \\
\text { conservation }\end{array}$ & Pay attention & Tend not to pay attention \\
\hline 4. & Production of the resulting sap & $\begin{array}{c}\text { Fewer }(<500 \text { trees per } \\
\text { hectare, rubber age }<40 \\
\text { years })\end{array}$ & Produce more sap \\
\hline 5. & $\begin{array}{l}\text { The diversity of yields from the } \\
\text { commodities planted }\end{array}$ & Produce more & $\begin{array}{c}\text { Only from rubber, it really } \\
\text { depends on the price }\end{array}$ \\
\hline 6. & Ease of maintenance & Easy and low cost & $\begin{array}{c}\text { Relatively expensive and } \\
\text { requires intensive } \\
\text { cultivation }\end{array}$ \\
\hline
\end{tabular}

Source : [20]

Farmers still experience several obstacles in the application of agroforestry in the field. The availability of capital and changes in the mindest of rubber farmers towards agroforestry must be the main concern, besides that government support for the development of agroforestry is still minimal [18, 19, 22]. From the existing literature studies, rubber plantation rejuvenation can be a starting point for developing agroforestry through the provision of superior seeds and provision of infrastructure both pre and post harvest, while some RAS models developed must continue to be introduced to farmers so that farmers' alternative choices are for profitable commodities. and suitable for agroecosystems (gardens and forests), so that the original purpose of agroforestry, namely environmental functions, can be fulfilled.

\section{Conclusion}

Domestic production and productivity of natural rubber are still the main problems because most of Indonesia's rubber trees are old and require attention. Natural rubber production produced from agroforestry systems still requires innovation and assistance to match the monoculture rubber cultivation system. The current management of agroforestry and monoculture rubber has provided significant socio-economic changes in farmers.

Rubber products produced from agroforestry and monoculture systems can be part of meeting the world's demand for rubber. The choice of rubber cultivation by means of agroforestry is an option for farmers as an alternative to cultivation with the condition that rubber management is carried out intensively both from the provision of production facilities and post-harvest so that the quantity and quality of rubber produced can be maintained.

The development of an agroforestry rubber system requires support between the business actors involved, including the government and the private sector. Thus, it can be seen that the challenges in the future need to be anticipated and synergized with the development of rubber cultivation, both in monoculture and agroforestry plantations, which 
can support each other with an agribusiness system that is interrelated for harmony with global demand.

We thank to Directorat General of Estate Crops, Ministry of Agriculture Indonesia and Association rubber of Indonesia (Gapkindo) for providing the data and information.

\section{References}

1. [BPS] Badan Pusat Statistik. Statistik Karet Indonesia 2019. Jakarta (ID). Badan Pusat Ststistika (2019) https://www.bps.go.id/publication/2020/11/30/bbe0914bad45c64c87c005fb/statisti k-karet-indonesia-2019.html

2. Indonesia EximBank. Proyeksi Ekspor Berdasarkan Industri: Komoditas Unggulan. Jakarta (2019). https://www.indonesiaeximbank.go.id/research/downloads/19.

3. [Ditjenbun]. Direktorat Jenderal Perkebunan. Statistik perkebunan Indonesia komoditas karet 2017- 2019. Jakarta (2018).

4. [IRSG] International Rubber Study Group. Rubber Statistical Bulletin (2019). http://www.rubberstudy.com

5. [Gapkindo]. Gabungan Perusahaan Karet Indonesia. Indonesia Natural Rubber Statistic Book. Jakarta (2018). http://www.gapkindo.org

6. K.F.S King, Chandler. The Wasted Land. The Program of Work of The International Council for Research in Agroforestry (ICRAF). Rome (1978). p. 1-39. http://apps.worldagroforestry.org/downloads/Publications/PDFS/B01036.pdf

7. A.F.S Budiman, E. Penot, H. de Foresta, T. Tomich. Integrated Rubber Agroforestry for the Future of Smallholder Rubber in Indonesia. Rubber National $\begin{array}{lllll}\text { Conference, } & \text { IRRI } & \text { (1994). } & \text { p. } & \text { 1-66. }\end{array}$ https://agritrop.cirad.fr/388080/1/ID388080.pdf

8. A. Welatama. JOM FISIP. https://jom.unri.ac.id/index.php/JOMFSIP/article/view/15918/15451

9. L.F. Syarifa, D.S. Agustina, C. Nancy, M. Supriadi. Jurnal Penelitian Karet. 34,1:119-126(2016). $\quad$ https://doi.org/10.22302/ppk.jpk.v34i1.218 https://ejournal.puslitkaret.co.id/index.php/jpk/article/view/218

10. Fair Rubber Association. Low Prices Drive Natural Rubber Producers Into Poverty: An overview of sustainability issues and solutions in the rubber sector. Amsterdam (NDL): Aidenvironment (2016).

11. W.R. Dillon, M. Goldstein. Multivariate Analysis Methods and Application. United Stated of America. John Wiley \& Sons.Inc(1984).p. 608.

12. F. Oktavia, M. Lasminingsih. Jurnal Penelitian Karet. 28,2:32-40(2010).

13. A.D. Andrijanto, Karno, A.M. Legowo. Jurnal Agromedia. 33,1:88-96(2015). https://doi.org/10.47728/ag.v33i1.107

14. [Puslit Karet]. Pusat Penelitian Karet. Analisis Kinerja dan Prospek Komoditas Karet. Direktorat Jenderal Perkebunan (2014).

15. [ANRPC] Association of Natural Rubber Producing Countries. Natural rubber trends \& statistics. Kuala Lumpur (MLY): Association of Natural Rubber Producing Countries (2018).

16. M.R. Syaffendi, A. Rifin, S. Jahroh. Jurnal Agribisnis Indonesia. 1,2:125142(2013). https://doi.org/10.29244/jai.2013.1.2.125-142

17. S. Suyanto, T.P. Tomich, K, Otsuka. Agroforestry Systems. 50,2:145-160(2001). doi:10.1023/A:1010625019030 
18. W. Sukmawati, Y. Arkeman, S.Maarif. Jurnal Teknik Industri. 4,1:58-64(2014). http://dx.doi.org/10.25105/jti.v4i1.1563

19. A.S. Muntasyarah. Agroforest di Jambi : dapatkah bertahan di era desentralisasi? Governance Brief. Center for International Forestry Research (CIFOR)(2006) p. 14.

20. H. de Foresta, A. Kusworo, G. Michon, W.A. Djatmiko. Ketika kebun berupa hutan. Agroforest Khas Indonesia. Sebuah Sumbangan Masyarakat. International Centre for Research in Agroforestry (ICRAF)(2000). p. 1-264

21. A. Gouyon, H. de Foresta, P. Levang. Agroforestry Systems. 22:181-206(1993). https://doi.org/10.1007/BF00705233

22. Prayogo, H. Fauzi, D. Naemah. Jurnal Sylva Scianteae. 3,4:709-719(2020). https://doi.org/10.20257/10.20527/jss.v6i3 